'Working capital management and shareholders' wealth creation: evidence from non-financial firms listed on the Johannesburg Stock Exchange"

\begin{tabular}{ll} 
AUTHORS & $\begin{array}{l}\text { Emmanuel Kojo Oseifuah } \\
\text { Agyapong Gyekye }\end{array}$ \\
& $\begin{array}{l}\text { Emmanuel Kojo Oseifuah and Agyapong Gyekye (2017). Working capital } \\
\text { management and shareholders' wealth creation: evidence from non-financial } \\
\text { firms listed on the Johannesburg Stock Exchange. Investment Management and } \\
\text { ARTICLE INFO }\end{array}$ \\
\hline Financial Innovations, 14(1), 80-88. doi:10.21511/imfi.14(1).2017.08
\end{tabular}

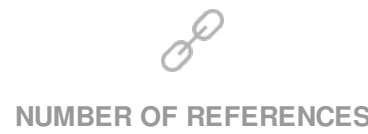

43
NUMBER OF FIGURES

0
NUMBER OF TABLES

6

(C) The author(s) 2022. This publication is an open access article. 
Emmanuel Kojo Oseifuah (South Africa), Agyapong Gyekye (South Africa)

\title{
Working capital management and shareholders' wealth creation: evidence from non-financial firms listed on the Johannesburg Stock Exchange
}

\begin{abstract}
Working capital plays a vital role in shareholders' wealth creation, yet there is a dearth of empirical studies on the relationship between working capital management and firm value in the South African economic environment. This study attempts to fill this gap by using Richards and Laughlin's (1980) Cash Conversion Cycle theory to investigate the impact of working capital management efficiency and its separate components on firm value of South African firms listed on the Johannesburg Stock Exchange (JSE). Panel data regression methodology was used to analyze accounting data obtained from I-Net Bridge/BFA McGregor for 75 firms for the 10 year period, 2003 to 2012, to determine the nexus between WCM and profitability (proxied by return on assets). The key findings of the study are as follows: 1) there exists a significant positive relationship between firm value and both inventory conversion period and receivables conversion period; 2) the relationship between the cash conversion cycle and firm value is positive but insignificant; 3) there is a significant positive relationship between accounts payable deferral period (PDP) and profitability; 4) firm size and firm value are significantly positively related, and 5) there is a significant negative relationship between leverage and firm value.
\end{abstract}

Keywords: firm value, Johannesburg Stock Exchange, market capitalization, shareholder wealth creation, working capital management.

JEL Classification: M41.

\section{Introduction}

According to Jensen (2001), the origins of the ideas shaping shareholder wealth maximization theory are more than 200 years old, with roots in Adam Smith's (1776) The Wealth of Nations. In general, shareholder theory encompasses the idea that the main purpose of business lies in generating profits and increasing shareholder wealth. Indeed, a review of corporate annual financial reports reveals that the SWM tenet is a fundamental principle, as well as a universal corporate objective. For example, Roberto Goizueta, the former CEO of the Coca-Cola Company (cited in Van Horne and Wachowicz, 2008, p. 1), points out that 'increasing shareholder value over time is the bottom line of every move we make'. McDonald (2006) puts it this way: '... we [the Board of Directors] are united in our goal to ensure McDonald strives to enhance shareholder value'. Philips (2006) declared that 'the desire to increase shareholder value is what drives our actions'. There is, therefore, no disputing that the shareholder wealth maximization principle is the driving force behind corporate finance. The implications of efficient working capital management for value creation

\footnotetext{
(C) Emmanuel Kojo Oseifuah, Agyapong Gyekye, 2017.

Emmanuel Kojo Oseifuah, Associate Professor, Department of Accountancy, University of Venda, South Africa.

Agyapong Gyekye, Emeritus Professor, Department of Economics, University of Venda, South Africa.

This is an Open Access article, distributed under the terms of the Creative Commons Attribution-NonCommercial 4.0 International license, which permits re-use, distribution, and reproduction, provided the materials aren't used for commercial purposes and the original work is properly cited.
}

for shareholders has been the focus of several empirical studies in developed countries. Most researchers have argued that efficient working capital management is very imperative in the realization of the shareholder wealth maximization objective, because it influences a firm's risk, profitability and ultimately shareholders' wealth (Smith, 1980; Deloof, 2003; Ganesan, 2007; Watson and Head, 2007; Kieschnick et al., 2013; Deutsche Bank, 2014; Boyce, 2014; Aktas, Croci, and Petmezas, 2015). Dong and Su (2010) echo the importance of working capital management and its consequence on shareholders wealth creation by emphasizing that working capital management is a continuous function which is linked to the survival of firms and if WCM is not given due consideration, the firm cannot survive for a longer period.

In another study, Watson and Head (2007) asserted that working capital management is a vital factor in a firm's long-term success and without the 'oil' of working capital, the 'engine' of fixed assets will not function. Consistent with the above studies is Ernst and Young's (2009) working capital study, which reported that the 2000 leading companies in the USA and Europe have ample opportunities to release liquidity of about US\$ 1 trillion from working capital during the 2008/2009 financial crisis. This finding is in agreement with Lai's (2012) study, which identified working capital as a catalyst for the resuscitation of most businesses worldwide after easing of the global financial crisis. In line with the above studies is REL's (2011) working capital survey, which reported that most large companies in Europe increased their revenue by $14.9 \%$ in 2010 
and have either maintained or increased their margin revenue, which is connected to working capital management.

Further still, Aktas, Croci, and Petmezas (2015) in their study of US businesses noted that at the end of 2011, the firms' total investment in working capital (i.e., inventory and receivables) amounted to $\$ 4.2$ trillion, which accounts for $24 \%$ of their total sales and about $18 \%$ of the book value of their assets (40\% of this aggregate working capital was financed by accounts payable, leading to an aggregate investment in net operating working capital (NWC) of $\$ 2.5$ trillion. On the basis of the results, Aktas et al. (2015) concluded that US businesses are of the view that working capital represents a significant portion of the total assets and total sales of businesses in the US. It is no surprise that Flanagan (2005) refers to working capital as the lifeblood of businesses, and, therefore, corporate managers must endeavor to keep working capital flowing and use the cash flows to generate profits.

It is therefore obvious to conclude that efficient management of working capital is value relevant to any company (de Almeida and Eid Jr., 2013). On the contrary, inefficient working capital management (WCM) has long been cited as a major cause of business failure in some developed economies like the USA, UK, Canada and Australia (Altman, 1968; Smith, 1973; Largay and Stickney, 1980; Pike and Pass, 1987; Shin and Soenen, 1998). For example, Altman's (1968) multivariate predictor model based on US companies includes working capital as one of the model's components. In a similar study in the UK, Taffler (1982) developed a four-variable model of failure prediction in which all the four variables include a variant on working capital as a component. It is no surprise that interest in WCM has assumed a greater significance now than ever before for businesses and researchers in the wake of the 2009 global financial crisis, which had strained the financial resources of many firms (Ernst and Young, 2009; Greenberg, 2009; Correia et al., 2011; Sagner, 2011). Based on the preceding discussions, it is argued in this study that WCM is undoubtedly a very important aspect of shareholders' wealth maximization process, because efficient WCM not only affects a firm's long-term survival, but also profitability, liquidity and ultimately its value. Therefore, an analysis of the effect of working capital management and its components on firm performance (profitability and value) is necessary and imperative in the South African environment.

Objectives. The objectives of the study are:

i) To evaluate the relationship between CCC and value (market capitalization) of JSE- listed firms. ii) To determine the relationship between ICP and value (market capitalization) of JSE- listed firms.

iii) To ascertain the relationship between $\mathrm{RCP}$ and value (market capitalization) of JSE- listed firms.

iv) To determine the relationship between PDP and value (market capitalization) of JSE- listed firms.

\section{Literature review}

Since Fama's (1970) pioneering work, several scholars have investigated the relationship between WCM (and its components) and firm value. Shin and Soenen (1998) provide good evidence of how important working capital management is for a company. They show that although Wal-Mart and Kmart (US retail firms) had comparable capital structures in 1994, Kmart went bankrupt mainly because of poor working capital management. Kmart had a cash conversion cycle of about 61 days, whereas Wal-Mart had a shorter conversion cycle of 40 days; consequently, Kmart faced an extra \$193.3 million per year in financing costs that was difficult to handle. More recently, Kieschnick et al. (2013) confirm the effect of working capital management on shareholder's wealth, but find cash to be valued higher in comparison to working capital. Additionally, they find evidence of the influence of other firm characteristics such as financing constraints on the valuation of working capital. Further investigations reveal that the investment in accounts receivable has a greater impact on shareholder wealth compared to the investment in inventories. In another study, Luo, Lee, and Hwang (2009) find that aside from the level of working capital efficiency, improvement in working capital management significantly affects future operating earnings. In addition, increasing accounts receivable (or trade credit to other firms) results in higher future performance. The study further found that the value of highly levered firms is positively affected by changes in working capital management policy meaning that the market actually views working capital management efficiency positively, although it also underreacts to working capital changes.

Strischek (2003) in his study The Impact of working capital Investment on the value of a company uses Rappaport's (1998) model to examine how better working capital management increases cash flow that, in turn, adds value to a company's equity (value). The results show that higher cash flows from better working capital management result in lower cost of capital and higher value of equity. Strischek (2003) concluded that "efficient working capital management means more cash flow to repay bankers and more value to reward investors. Working capital just may be the most interesting and fertile subject of finance". Kieschnick et al. (2008) similarly examined the relationship between work- 
ing capital management and firm value based on Faulkender and Wang's (2006) valuation model. The results revealed that the value assigned to investment in net working capital (NWC) is lower than that of cash and that reduction in firm value is due to its financing and the additional dollar invested in NWC. This result was confirmed by Autukaite and Molay (2011). Rezaee et al. (2013) also analyzed the effects of working capital management on firm's performance measured using Adjusted Economic Value Added (AEVA) and Market Value Added (MVA). The results indicated that there is no significant relationship between working capital management and both AEVA and MVA.

The relationship between WCM and performance of firms' listed on the Nigerian Stock Exchange was carried out by Ogundipe, Idowu, and Ogundipe (2012). The authors analyzed annual reports of fifty four non-financial quoted firms on the Nigerian Stock Exchange (NSE) for the period 1995-2009. The findings revealed that working capital management (measured by the cash conversion cycle) has a negative relationship with market valuation (Tobin's Q), while debt ratio (leverage) is positively related to market valuation (Tobin's Q). De-Almeida and Eid Jr (2014) also analyzed the effect of investment in working capital on firm value. Working capital was measured by investment in current assets, while firm value was proxied by excess stock return. The results of the study show that an extra investment in working capital is significantly less worth, on average, than an extra investment in cash. Also, on average, increasing the level of working capital at the beginning of a fiscal year reduces company value.

Baños-Caballero et al. (2011) examined the link between working capital and business performance and found that the relationship between working capital investment and firm performance is not linear, implying that there is an optimal level of working capital that would be able to found that the optimal level of working capital for financially constrained firms is lower than those of unconstrained firms. The studies so far on working capital and firm value confirm two things. First, working capital does influence firm value significantly and, second, financing constraints play an important part in this relationship. However, the studies are still limited and further empirical evidence is needed to support these findings.

A variety of metrics were employed to measure working capital management in the above studies. These include the cash conversion cycle (CCC), the operating cycle (OC), net liquid balance (NLB), the net-trade cycle (NTC) and the weighted cash conversion cycle (WCCC). Of all the WCM metrics, the cash conversion cycle has been identified as the best measure of working capital efficiency (Karaduman, Akbas, Ozsozgun, and Durer, 2010). Similarly, firm value was measured by different metrics including market capitalization, Enterprise Value (EV), Capital Asset Pricing Model (CAPM) and Arbitrage Pricing Models (APM), Tobin's Q, Adjusted Economic Value Added (AEVA), Market Value Added (MVA), and the discounted cash model. According to Damodaran (2010), data for estimating the above metrics, except market capitalization, are problematic due to unavailability or inaccessibility to data. For the purposes of the present study, market capitalization (market cap) was used as the most appropriate metric for measuring firm value, because the data are publicly available and accessible from the JSE.

Market capitalization may be defined as the total tradable value of a company. It is equal to the number of shares outstanding at the end of the financial year multiplied by the share price. The market cap represents the value the market places on the entire company. It is, therefore, an indicator of public opinion on the total future value or net worth of a company. The market cap is a measure of equity, that is, the ownership of a business, though not the most accurate measure of firm value, as it ignores the other essential component of a firm's capital debt. To get around this, investors commonly use a variant of market cap - enterprise value (EV). Mathematically, EV = Market cap plus debt minus cash. This measures how much it would cost someone to buy out all the owners of a firm, pay off all debts, and take out any cash left over. Furthermore, even though market values are typically considered the most accurate, there are also some challenges with this metric. For example, shares that are traded at low volumes may be undervalued, as fears of a lack of liquidity could result in lower demand, and hence, lower share prices. Conversely, overvaluation may result from increased market confidence, rather than any actual improvements in corporate activity.

Despite these short comings, market cap is an important economic measure for several reasons. First, it can easily be calculated from data that are readily and widely available. Second, investors can compare market cap to financial data to evaluate the price relative to fundamental returns. Market cap is also useful for identifying the type of stock and setting appropriate growth, risk and dividend expectations. More importantly, market capitalization has been used as an input in popular valuation metrics such as price to earnings, price to free cash flow, Tobin's Q, price to book value and enterprise value to EBITDA. Third, the total market cap can be used as a measure of stock market performance. It can 
also be used as economic indicator, providing a comparison of business activity, both in total size and growth, between economic regions. Market cap is also used as a key factor in stock valuation. Stock market indices typically represent changes in market capitalization of a basket of selected firms, while the most important quoted market indices tend to be based on the market cap of companies. For example, JSE Top 40 Shares, the US S\&P 500, Hong Kong Hang Seng, UK FTSE 100, Euro Stoxx, German DAX, JSE 40, indices are all composed of the largest shares by market capitalization.

Based on the reviewed literature, we formulate the following hypotheses:

Hypothesis 1: There is a negative relationship between the cash conversion cycle (CCC) and value (market capitalization) of JSE-listed firms.

Hypothesis 2: There is a negative relationship between the inventory conversion period (ICP) and value (market capitalization) of JSE-listed firms.

Hypothesis 3: There is a negative relationship between the receivables conversion period (RCP) and value (market capitalization) of JSE-listed firms.

Hypothesis 4: There is a positive relationship between the payables deferral period (PDP) and value (market capitalization) of JSE-listed firms.

\section{Methodology}

The following model was employed to estimate the relationship between WCM, its discrete components and firm value. The model can be stated as follows:

$$
Y_{i t}=\beta_{0}+\beta_{k} X_{i t}+v_{i t}+\varepsilon_{i t},
$$

where $Y_{i t}$ is firm value (market capitalization) for firm $i$ in year $t$; $X_{i t}$ is RCP, ICP, PDP, CCC, GDPGR, CATA, LEV, and SIZE; $\beta_{0}, \beta_{1}, \ldots$ is regression co-efficient; $v_{i t}$ is individual error component (a particular characteristic of each firm); $\varepsilon_{i t}$ is the idiosyncratic error (unobservable factors) that vary over time and affect profitability. $\mathrm{i}$ is $1,2,3, \ldots, 75$ (firms); $t$ is 2003, 2004..., 2012 (time); $k$ is $1,2,3, . .10$.

\section{Population}

The population for the study comprises all firms listed on the JSE over the period, 2003 to 2012. As at 31 December 2012, a total of 335 firms were listed on the main board of which financial firms represent 27.2 per cent (91 firms). The remaining $72.8 \%$ (244) non-financial firms were, then, segmented according to the JSE Industry Classification Benchmark (ICB) as shown in Table 1 .

Table 1. Categories of firms listed on the JSE main board at 31 December 2012

\begin{tabular}{|c|l|c|c|}
\hline No. & ICB Industry Long Name & No. of firms & $\%$ of population \\
\hline 1 & Basic materials & 74 & $22.1 \%$ \\
\hline 2 & Consumer goods & 26 & $7.8 \%$ \\
\hline 3 & Consumer services & 44 & $13.1 \%$ \\
\hline 4 & Financials & 91 & $27.2 \%$ \\
\hline 5 & Healthcare & 7 & $2.1 \%$ \\
\hline 6 & Industrials & 70 & $20.9 \%$ \\
\hline 7 & Oil \& Gas & 4 & $1.2 \%$ \\
\hline 8 & Technology & 14 & $4.2 \%$ \\
\hline 9 & Telecommunications & 5 & $1.5 \%$ \\
\hline & Total & 335 & $100 \%$ \\
\hline
\end{tabular}

Source: JSE.

\section{Sample}

A sample of 75 firms listed on the main board of the JSE was selected from the target population. To arrive at the sample, the study excluded financial firms. This is due to the fact that financial firms have different accounting regulations that are relatively different from those required by nonfinancial firms (Deloof, 2003). Also, and as argued by Falope and Ajilore (2009), financial services firms' financial characteristics and investment in working capital are fundamentally different from nonfinancial firms. Lastly, the exclusion of the financial services firms allows for easy comparability with prior studies, which also excluded financial services firms (e.g., Deloof, 2003; Lazaridis and Tryfonidis, 2006; Falope and Ajilore, 2009; Kieschnick, Laplante, and Moussawi, 2013). To be included in the final sample, companies must have their complete financial statements for the entire period under consideration, that is, from 1 January 2003 to 31 December 2012 inclusive. As a result of the application of the above criteria, the final sample was narrowed down to 75 non-financial firms, which represent $22.4 \%$ of firms listed on the JSE as at 31 December 2012 shown in Table 2.

Table 2. Listed non-financial firms with complete data (1 Jan 2003 to 31 Dec 2012)

\begin{tabular}{|c|l|c|c|c|c|}
\hline & \multicolumn{1}{|c|}{ Industry } & No. of firms & Percent of sample selected & Percent of population of JSE listed firms & Market CAP (R billion) \\
\hline 1 & Basic materials & 12 & $16.00 \%$ & $3.58 \%$ & 3939.49 \\
\hline 2 & Consumer goods & 1 & $1.33 \%$ & $0.30 \%$ & 110.43 \\
\hline 3 & Consumer services & 23 & $30.67 \%$ & $6.87 \%$ & 2756.457 \\
\hline 4 & Healthcare & 3 & $4.00 \%$ & $0.90 \%$ & 515.46 \\
\hline 5 & Industrials & 25 & $33.33 \%$ & $7.46 \%$ & 1635.488 \\
\hline 6 & Oil \& Gas & 2 & $2.67 \%$ & $0.60 \%$ & 1755.94 \\
\hline
\end{tabular}


Table 2 (cont.). Listed non-financial firms with complete data (1 Jan 2003 to 31 Dec 2012)

\begin{tabular}{|c|l|c|c|c|c|}
\hline & \multicolumn{1}{|c|}{ Industry } & No. of firms & Percent of sample selected & Percent of population of JSE listed firms & Market CAP (R billion) \\
\hline 7 & Technology & 7 & $9.33 \%$ & $2.09 \%$ & 36.74 \\
\hline 8 & Telecommunications & 2 & $2.67 \%$ & $0.60 \%$ & 2338.52 \\
\hline Total & & 75 & 100.00 & $22.4 \%$ & 13088.53 \\
\hline
\end{tabular}

\section{Data analysis}

The study uses secondary financial data obtained from both the I-Net Bridge/McGregor BFA data base at the University of Pretoria library and the Johannesburg Stock Exchange (JSE), covering 2003 -2012. The final sample is a strongly balanced panel data of 750 firm-year observations, related to 75 different firms, during the period 2003-2012.

\section{Model specification}

Four models were employed to test the 4 hypotheses. The models regress firm value (market capitalization) for firm $i$ at time $t$ on CCC and each component of CCC (ICP, RCP and PDP), in addition to the included control variables as follows:

$$
\begin{aligned}
& M V=\beta_{0}+\beta_{1} C C C_{i t}+\beta_{2} S_{I Z E_{i t}}+\beta_{3} L E V_{i t}+ \\
& +\beta_{4} C A T A_{i t}+\beta_{5} G D P_{i t}+\varepsilon_{i t}, \\
& M V=\beta_{0}+\beta_{1} I C P_{i t}+\beta_{2} S_{I Z E_{i t}}+\beta_{3} L E V_{i t}+ \\
& +\beta_{4} C A T A_{i t}+\beta_{5} G D P_{i t}+\varepsilon_{i t}, \\
& M V=\beta_{0}+\beta_{1} R C P_{i t}+\beta_{2} S I Z E_{i t}+\beta_{3} L E V_{i t}+ \\
& +\beta_{4} C A T A_{i t}+\beta_{5} G D P_{i t}+\varepsilon_{i t}, \\
& M V=\beta_{0}+\beta_{1} P D P_{i t}+\beta_{2} S I Z E_{i t}+\beta_{3} L E V_{i t}+ \\
& +\beta_{4} C A T A_{i t}+\beta_{5} G D P_{i t}+\varepsilon_{i t},
\end{aligned}
$$

In the equations above, $i$ refers to firms and $t$ to time periods. The dependent variable MV measures firm value using market capitalization. $\beta_{0}$ is the intercept term; $\beta_{1}$ is the slope (coefficient or parameter estimate) of CCC; $\beta_{2}$ is the slope (coefficient or parameter estimate) of SIZE; $\beta_{3}$ is the slope of Leverage; $\beta_{4}$ is the slope of CATA; $\beta_{5}$ is the slope of GDP. The $u_{i}$ measures the unobservable heterogeneity of the individual specific effects of each firm, and $\varepsilon_{i}$ is the error term. Model specification (1) determines the impact of CCC, size, leverage, CATA, and GDP on firm value for all the selected years, 2003 to 2012. Model specification (2) determines the impact of ICP, size, leverage, CATA, and GDP on firm value for all the selected years, 2003 to 2012. Model specification (3) determines the impact of RCP, size, leverage, CATA, and GDP on firm value for all the selected years, 2003 to 2012. Lastly, model specification (4) determines the impact of PDP, size, leverage, CATA, and GDP on firm value for all the selected years, 2003 to 2012.

\section{Results and discussion}

This section provides the results of the empirical analysis conducted (using Stata Perpetual Statistical Software version 14) to observe the working capital efficiency and performance of JSE-listed nonfinancial firms. Three statistical techniques, univariate, bivariate and multivariate analyses, were used to analyze the nexus between firm value and working capital management. These are presented and discussed in the following sub-sections.

\section{Descriptive statistics}

The descriptive statistics (mean, standard deviation, minimum and maximum values) for firm value, working capital variables, and the control variables are reported in Table 3.

Table 3. Descriptive statistics for dependent and independent variables

\begin{tabular}{|l|l|l|l|l|c|c|}
\hline \multicolumn{1}{|c|}{ Panel } & \multicolumn{1}{|c|}{ Variable } & Obs & Mean & Std. Dev. & Min & Max \\
\hline Panel A & MKTCAP & 663 & 19.74136 & 51.33173 & 0 & 491.66 \\
\hline \multirow{4}{*}{$\begin{array}{l}\text { Panel B } \\
\text { (Main independent variables) }\end{array}$} & ICP & 744 & 48.7661 & 48.11304 & 0 & 307.26 \\
\cline { 2 - 8 } & RCP & 749 & 51.84157 & 30.92044 & 0 & 242.54 \\
\cline { 2 - 8 } & PDP & 744 & 80.33298 & 64.01277 & 0 & 502.1724 \\
\cline { 2 - 8 } & CCC & 749 & 19.94004 & 66.22835 & -393 & 297 \\
\hline \multirow{2}{*}{$\begin{array}{l}\text { Panel C } \\
\text { (Firm level control variables) }\end{array}$} & SIZE & 749 & 14.45351 & 3.626404 & 0 & 89.88 \\
\cline { 2 - 8 } & LEV & 749 & 4.720521 & 54.16175 & 0 & 0.99 \\
\cline { 2 - 8 } & CATA & 749 & .5892256 & .2509238 & 0 & 1.00 \\
\hline $\begin{array}{l}\text { Panel D } \\
\text { (External variable) }\end{array}$ & GDP & 750 & 3.51 & 1.991529 & -1.5 & 5.6 \\
\hline
\end{tabular}

Panel A describes the dependent variable - firm value (market capitalization). Panel $\mathrm{B}$ describes the main independent variables, while panels $\mathrm{C}$ and $\mathrm{D}$ describe the control variables. Firm value (market capitalization) ranges from 0 to 491.66 billion, with a mean of R19.74 billion and a volatility of $51.3 \%$. A zero was recorded, because some of the companies do not have data for some of the years. Inventory conversion period (ICP) is, on average, 49 days, which indicates that it takes the average firm 
within the sample about one month and 19 days to turnover inventory. It has a range of 0 day minimum 307 days maximum. The standard deviation of 48.1 days shows that the sample firms have a close variation of inventory turnover. The minimum inventory turnover of zero is due to the fact that some firms do not have inventory, hence, have no inventory turnover days. Accounts receivable conversion period (RCP) ranges from a minimum of 0 day to a maximum of 243 days with an average collection period of 51.8 days. This means that it takes approximately 1 month and 3 weeks for the sampled firms to collect monies owed by customers. As with ICP, the minimum RCP of 0 means that some firms do not have debtors. A standard deviation of 30.9 days suggest that there is less variation of accounts receivable period between the firms. For accounts payable deferral period (PDP), the average is 80.2 days and a minimum and maximum of 0 and 502.2 days, respectively. The results show that firms take on average, 2 months and 3 weeks to pay their creditors/suppliers. A standard deviation of 64 days suggest that suppliers' payment patterns varies widely.

The cash conversion cycle (CCC) ranges from -393 days to 297 days with a mean of approximately 20 days. The shorter average CCC shows that JSElisted firms manage their working capital efficiently by converting inventory into goods for sale as possible and also collecting monies owed by customers quickly, but pay their suppliers as late as possible. In practical terms, this means that it takes an average about 3 weeks' time for the sampled JSE-listed firms to convert a rand of cash disbursements back into a rand of cash inflow from their regular course of operations. Firm size ranges from a minimum of R0 to R89.99 billion with an average size of R14.4 billion. Since turnover was used as a proxy for firm size, then, a size of R0 means that a firm did not make any sales in a particular year. The average financial leverage ratio of the sampled firms is 0.54 and ranges from a minimum of 0 to a maximum of 0.99 . The mean leverage of 0.54 means that most of the sampled firms are using approximately $54 \%$ of debt to finance their businesses. The current assets to total assets ratio (CATA) ranges from a minimum of 0 to a maximum of 1.0 with a mean of 0.59 . This key ratio is important from the view point of liquidity. The higher the CATA, the higher the liquidity and vice versa. Thus, the reported CATA of 0.59 implies that, on average, 59\% of the sampled firms' total investment was made for working capital. Lastly, annual real GDP growth rate was introduced to control for the evolution of the economic cycle. That is, to capture economic factors that may affect firms' profitability that vary over time, but remain constant across firms. The reported GDP growth rate ranges from $-1.5 \%$ minimum to $5.6 \%$ maximum with a mean of $3.51 \%$. The range shows that the economy moved from recession $(-1.5 \%)$ to boom over the 10 year period. The recession occurred in 2009 due to the global financial and crises. The effect of the recession is, therefore, expected to reflect in the performance of the firms in terms of lower profitability and firm value.

\section{Bivariate analysis}

We examined all the variables and their traits individually to assess the degree of linear relationship among all variables using Pearson product-moment correlation coefficient. Table 4 presents the Pearson product-moment correlation coefficient matrix for all the variables that were used in the regression model.

Table 4. Correlation matrix of firm value, WCM components and control variables

\begin{tabular}{|c|c|c|c|c|c|c|c|c|c|}
\hline & MKTCAP & $\operatorname{CCC}$ & ICP & RCP & PDP & SIZE & LEV & GDP & CATA \\
\hline MKTCAP & 1.0000 & & & & & & & & \\
\hline $\mathrm{CCC}$ & $\begin{array}{l}0.1103^{*} \\
(0.0045)\end{array}$ & 1.0000 & & & & & & & \\
\hline ICP & $\begin{array}{l}0.1190^{*} \\
(0.0023)\end{array}$ & $\begin{array}{l}0.4443^{*} \\
(0.0000)\end{array}$ & 1.0000 & & & & & & \\
\hline $\mathrm{RCP}$ & $\begin{array}{c}0.0378 \\
(0.3314)\end{array}$ & $\begin{array}{l}0.2417^{*} \\
(0.0000)\end{array}$ & $\begin{array}{l}0.0881^{*} \\
(0.0000)\end{array}$ & 1.0000 & & & & & \\
\hline PDP & $\begin{array}{c}-0.0052 \\
(0.8940)\end{array}$ & $\begin{array}{l}-0.5848^{*} \\
(0.0000)\end{array}$ & $\begin{array}{l}0.3310^{*} \\
(0.0000)\end{array}$ & $\begin{array}{l}0.2986^{*} \\
(0.0000)\end{array}$ & 1.0000 & & & & \\
\hline SIZE & $\begin{array}{l}0.2392^{*} \\
(0.0000)\end{array}$ & $\begin{array}{l}0.1579^{*} \\
(0.0000)\end{array}$ & $\begin{array}{l}0.1214^{*} \\
(0.0009)\end{array}$ & $\begin{array}{c}0.0574 \\
(0.1166) \\
\end{array}$ & $\begin{array}{l}-0.0399 \\
(0.2767) \\
\end{array}$ & 1.0000 & & & \\
\hline LEV & $\begin{array}{l}-0.1302^{*} \\
(0.0418)\end{array}$ & $\begin{array}{l}-0.0691 \\
(0.2475)\end{array}$ & $\begin{array}{l}-0.0340 \\
(0.5730)\end{array}$ & $\begin{array}{l}0.1994^{*} \\
(0.0008)\end{array}$ & $\begin{array}{l}0.1810^{*} \\
(0.0025)\end{array}$ & $\begin{array}{l}0.1169^{*} \\
(0.0499)\end{array}$ & 1.0000 & & \\
\hline GDP & $\begin{array}{l}-0.0624 \\
(0.1084)\end{array}$ & $\begin{array}{l}-0.0274 \\
(0.4540)\end{array}$ & $\begin{array}{l}-0.0251 \\
(0.4939)\end{array}$ & $\begin{array}{c}0.0428 \\
(0.2421)\end{array}$ & $\begin{array}{c}0.0283 \\
(0.4415)\end{array}$ & $\begin{array}{l}-0.0838^{*} \\
(0.0218)\end{array}$ & $\begin{array}{l}0.1333^{*} \\
(0.0252)\end{array}$ & 1.0000 & \\
\hline CATA & $\begin{array}{l}-0.1559^{*} \\
(0.0001)\end{array}$ & $\begin{array}{l}-0.0191 \\
(0.6018)\end{array}$ & $\begin{array}{l}0.1832^{*} \\
(0.0000)\end{array}$ & $\begin{array}{l}0.1498^{*} \\
(0.0000)\end{array}$ & $\begin{array}{l}0.2258^{*} \\
(0.0000)\end{array}$ & $\begin{array}{l}-0.1027^{\star} \\
(0.0049)\end{array}$ & $\begin{array}{c}0.1117 \\
(0.0609)\end{array}$ & $\begin{array}{c}0.0147 \\
(0.6883)\end{array}$ & 1.0000 \\
\hline
\end{tabular}

Notes: Significant at $1 \%(* * *), 5 \%(* *)$, and $10 \%(*)$ levels respectively; p-values in parentheses. 
Surprisingly, there is a significant positive correlation between firm value and both CCC and ICP, and an insignificant positive relationship between firm value and RCP. As expected, there is a negative relationship between firm value and PDP. However, the relationship between PDP and firm value is not significant.

\section{Regression analysis}

To further establish the relationship between working capital management (WCM) and firm's market value, we apply multivariate regression analysis, that is, OLS regression analysis and panel data regression analysis.

\section{OLS regression analysis}

Hypothesis (1) predicts that all things being equal, there is a negative relationship between firm value and WCM. In order to test this hypothesis, the study regressed firm value on working capital management variables in addition to the included control variables. The results of the OLS regression are presented in Table 5.

Table 5. OLS regression analysis of the relationship between firm value and WCM

\begin{tabular}{|l|c|c|c|c|}
\hline \multirow{2}{*}{ CCC } & $(1)$ & $(2)$ & $(3)$ & $(4)$ \\
\cline { 2 - 5 } & MKTCAP & MKTCAP & MKTCAP & MKTCAP \\
\hline \multirow{2}{*}{ SIZE } & $0.198^{*}$ & & & \\
& $(0.018)$ & & & \\
\hline \multirow{2}{*}{ LEV } & 1.596 & 1.508 & 1.717 & 1.968 \\
& $(0.110)$ & $(0.110)$ & $(0.072)$ & $(0.084)$ \\
\hline \multirow{2}{*}{ GDP } & -23.96 & -21.75 & $-35.40^{*}$ & $-34.00^{*}$ \\
& $(0.060)$ & $(0.081)$ & $(0.024)$ & $(0.033)$ \\
\hline \multirow{2}{*}{ CATA } & -3.330 & -3.710 & -3.442 & -3.339 \\
& $(0.244)$ & $(0.187)$ & $(0.227)$ & $(0.241)$ \\
\hline \multirow{2}{*}{ ICP } & $46.04^{* * *}$ & $-63.05^{* * *}$ & $-56.02^{* * *}$ & $-47.12^{* * *}$ \\
& $(0.000)$ & $(0.000)$ & $(0.000)$ & $(0.000)$ \\
\hline \multirow{2}{*}{ RCP } & $0.376^{* *}$ & & & \\
& $(0.010)$ & & & \\
\hline \multirow{2}{*}{ PDP } & $0.450^{* *}$ & & & \\
\hline \multirow{2}{*}{ Cons } & $(0.007)$ & & & \\
& $0.174^{*}$ & & & \\
\hline R-sq & $(0.039)$ & & & 37.56 \\
\hline F & $(0.062)$ & $(0.061)$ & $(0.095)$ & $(0.104)$ \\
\hline N & 0.119 & 0.163 & 0.127 & 0.097 \\
\hline
\end{tabular}

Notes: P-values in parentheses; $* \mathrm{p}<0.05$, ** $\mathrm{p}<0.01$, $* * * \mathrm{p}<0.001$

The results from the OLS analysis show that both cash conversion cycle, inventory conversion, and receivables conversion period are significantly positively related to firm value, which contradicts Hypotheses (1) to (3), respectively. We also observe that there is a positive and a significant relationship between receivables conversion period and firm value, which is consistent with Hypothesis (3). The next section uses random effects (RE) panel data regression to test the relationship between firm value and working capital management.

\section{Panel data regression analysis}

The following independent variables are considered to analyze their impact on firm value. CCC measures the average number of days-sales which the company has to finance its working capital needs $(\mathrm{CCC}=\mathrm{ICP}+\mathrm{RCP}-\mathrm{PDP})$. RCP measures the average number of days-sales of accounts receivable. ICP measures the average number of days-sales on inventories. PDP measures the average number of days-sales of accounts payable. The control variables are as follows: Size is firms' size proxy measured by the logarithm of assets, CATA is the ratio of current assets investment to total assets investment, and GDP is the annual real GDP growth rate in South Africa. The results obtained for equations (1) to (4) using the RE methodology are reported in Table 6.

Table 6. Effect of WCM on firm value using random effect (RE) regression estimation

\begin{tabular}{|c|c|c|c|c|}
\hline & (1) & (2) & (3) & (4) \\
\hline & MKTCAPT & MKTCAP & MKTCAP & MKTCAP \\
\hline CCC & $\begin{array}{l}0.0858 \\
(0.174)\end{array}$ & & & \\
\hline SIZE & $\begin{array}{l}1.237^{*} \\
(0.050)\end{array}$ & $\begin{array}{c}1.232 \\
(0.055)\end{array}$ & $\begin{array}{c}1.124 \\
(0.067)\end{array}$ & $\begin{array}{c}1.244 \\
(0.050)\end{array}$ \\
\hline LEV & $\begin{array}{l}-40.03^{*} \\
(0.015)\end{array}$ & $\begin{array}{l}-34.48 \\
(0.032)\end{array}$ & $\begin{array}{c}-49.08^{\star *} \\
(0.003)\end{array}$ & $\begin{array}{c}-45.79^{\star *} \\
(0.006)\end{array}$ \\
\hline GDP & $\begin{array}{c}-3.346 \\
(0.055)\end{array}$ & $\begin{array}{l}-3.478 \\
(0.054)\end{array}$ & $\begin{array}{l}-3.622^{*} \\
(0.032)\end{array}$ & $\begin{array}{l}-3.305 \\
(0.062)\end{array}$ \\
\hline CATA & $\begin{array}{r}-30.23 \\
(0.115) \\
\end{array}$ & $\begin{array}{c}-44.20^{*} \\
(0.020) \\
\end{array}$ & $\begin{array}{c}-47.07^{*} \\
(0.018)\end{array}$ & $\begin{array}{l}-35.13 \\
(0.072)\end{array}$ \\
\hline ICP & $\begin{array}{l}0.250^{\star *} \\
(0.005)\end{array}$ & & & \\
\hline $\mathrm{RCP}$ & $\begin{array}{c}0.497^{\star \star \star} \\
(0.000)\end{array}$ & & & \\
\hline PDP & $\begin{array}{l}0.147^{\star} \\
(0.038)\end{array}$ & & & \\
\hline _cons & $\begin{array}{l}50.39^{\star *} \\
(0.002)\end{array}$ & $\begin{array}{l}44.13^{\star *} \\
(0.006)\end{array}$ & $\begin{array}{l}43.10^{\star *} \\
(0.007)\end{array}$ & $\begin{array}{l}47.54^{* *} \\
(0.004)\end{array}$ \\
\hline $\mathrm{N}$ & 245 & 240 & 245 & 240 \\
\hline
\end{tabular}

Notes: P-values in parentheses; $* \mathrm{p}<0.05$, ** $\mathrm{p}<0.01$, $* * * \mathrm{p}<0.001$.

The results in Table 6 show that both inventory conversion period and receivable conversion period are significantly positively related to firm value, which contradicts Hypotheses (2) and (3). We also observe that $\mathrm{CCC}$ has an insignificant positive relationship with firm value which is inconsistent with Hypothesis (1). Lastly, the results show that there is a significant positive relationship between payable deferral period and firm value, which is consistent with Hypothesis (4).

\section{Conclusion}

The study investigated the relationship between firm value and WCM as well as the relationship between 
firm value and the separate components of WCM for a sample of 75 non-financial firms listed on the Johannesburg Stock Exchange (JSE). The results show that both receivables conversion period and inventory conversion period are significantly positively related to firm value (market capitalization), which is inconsistent with the hypotheses that ICP and RCP are negatively related to firm value. Although our results are inconsistent with our hypotheses, studies in India by Sharma and Kumar (2011) and by Baveld (2012) in the Netherlands support the positive relationship between accounts receivable and inventory conversion period with firm value in particular during the 2008-2009 financial crises period (Baveld). This finding in our study may be explained in the case of South Africa that instead of adopting the so called "carrot-and-stick" approach to accounts receivable policies, credit policies may be relaxed to accommodate more customers, instead of offering early bird discount. As a consequence, the accounts receivable may be elongated in an effort to improve firm profitability and consequently firm value. The results, however, confirm that payables deferral period is significantly positively related to firm value. This means that firms can enhance their value by negotiating longer payment terms from their creditors.

The results further show that firm size has a significant positive relationship with firm value confirming the theory that size of a firm is a primary factor in determining the profitability and market value of a firm due to economies of scale, which can be found in the traditional neo-classical view of the firm (Bhattacharyya and Saxena, 2009). It reveals that, contrary to smaller firms, items can be produced on much lower costs by bigger firms. In accordance with this concept, a positive relationship between corporate size and profitability and market value is expected (Tangen, 2003). Lastly, the panel data regression analysis reveals that there is a significant negative relationship between leverage and firm value. This means that the level of debt a firm has in its capital structure is a factor that will affect its value. This result is consistent with Rayan's (2008) study who found a significant negative relationship between debt and value of firms listed on the Johannesburg Stock Exchange during the period 1998-2007.

\section{References}

1. Adam, S. (1776). An Inquiry into the Nature and Causes of the Wealth of Nations. 1 (1 Ed.). London

2. Altman, E. (1968). Financial Ratios, Discriminant Analysis and Prediction of Corporate Bankruptcy. The Journal of Finance, 589-609.

3. Anderson, E. W., Fornell, C., and Mazvancheryl, S. K. (2004). Customer Satisfaction and Shareholder Value. Journal of Marketing, 68 (October), 172-185.

4. Aktas, N., Croci, E., and Simsir, S. A. (2016) Corporate Governance and Takeover Outcomes. Corporate Governance: An International Review, 24, 242-252. doi: 10.1111/corg.12116

5. Autukaite, and Molay. (2011). Cash holding, working capital and fir value: evidence from France. International conference of the French Finance association (AFFI), 11-13.

6. Baños-Caballero, S., García-Teruel P., and Martínez-Solano, P. (2014). Working Capital Management, Corporate Performance, and Financial Constraints. Journal of Business Research, 67(3), 332-338.

7. Baveld, M. B. (2012). Impact of Working Capital Management on the Profitability of Public Listed Firms in The Netherlands During the Financial Crisis. Unpublished Master's Thesis. University of Twente.

8. Bhattacharyya, S., and Saxena, A. (2009). Does firm size matter? An empirical enquiry into the performance of Indian manufacturing firms. MPRA Paper No. 13029.

9. Correia, C., Flynn, D., Uliana, E., \& Wormald, M. (2010). Financial management (7th ed.). Cape Town: Juta.

10. Damodaran, A. (2012). Investment Valuation: Tools and Techniques for Determining the Value of any Asset. Wiley Finance, 3rd Edition.

11. De Almeida, J. R., and Eid Jr. W. (2013). Access to Finance, Working Capital Management and Company Value: Evidences from Brazilian Companies Listed on BM\&FBOVESPA. Journal of Business Research, 67, 924-934.

12. Deloof, M. (2003). Does Working Capital Management Affect Profitability of Belgian Firms? Journal of Business Finance \& Accounting, 30(3 and 4), 573-587.

13. Dong, H. P., Su, J. (2010). The Relationship between Working Capital Management and Profitability: A Vietnam Case. International Research Journal of Finance and Economics, 49, 59-67.

14. Ernst, L., \& Young, G. (2009). All tied-up Working capital management report -2009. Retrieved from http://www.ey.com/Publication/vwLUAssets/All-tied-up_2009/\$FILE/All-tied-up_2009.pdf.

15. Falope, O. I., Ajilore, O. T. (2009). Working Capital Management and Corporate Profitability: Evidence from Panel Data Analysis of Selected Quoted Companies in Nigeria. Research Journal of Business Management, 3, $73-84$.

16. Fama, E. (1970). Efficient Capital Markets: A Review of Theory and Empirical Work. Journal of Finance, 25, 383-417.

17. Faulkender, M., \& Wang, R. (2006). Corporate Financial Policy and the Value of Cash. Journal of Finance, forthcoming.

18. Ganesan, V. (2007). An Analysis of Working Capital Management Efficiency in Telecommunication Equipment Industry. Rivier Academic Journal, 3, 1-10. 
19. Greenberg, L. (2009). Liberating Cash: Reducing working capital levels. Association for Financial Professionals.www.AFPonline.org.

20. Karaduman, H. A., Akbas, H. E., Ozsozgun, A., \& Durer, S. (2010). Effects of working capital management on profitability: The case of selected companies in Istanbul Stock Exchange (2005-2008). International Journal of Economics and Finance Studies, 2(2), 47-54.

21. Kienschnick, R., LaPlante, M., \& Moussawi, R. (2006). Corporate working capital management: determinants and consequences. [Online] Available: http://www.fma.org/SLC/Papers/cwcmf_fma.pdf (December 10, 2014).

22. Largay, J., and C. Stickney (1980). Cash flows, ratio analysis and the W. T. Grant Bankruptcy. Financial Analysts Journal, 46(July-August), 51-54.

23. Lazaridis, D. I., \& Tryfonidis, D. (2006). Relationship between working capital management and profitability of listed companies in the Athens stock exchange. Journal of Financial Management and Analysis, 19(1), 26-35.

24. Luo, M. M., Lee, J. J., and Hwang, Y. (2009). Cash conversion cycle, firm performance and stock value. Retrieved from www90.homepage.villanova.edu/Michael.../ML_CCC_20090420.pdf

25. Ogundipe, L. O., Ogundipe, S. E., \& Ajao, S. K. (2012). Cash holding and firm characteristics: Evidence from Nigerian emerging market. Journal of Business Economics and Finance, 1(2), 45-58.

26. Pike, R. H., and Pass, C. L. (1984). An Overview of Working Capital Management and Corporate Financing. Managerial Finance, 10(3), 1-11.

27. Rajan, K. (2008). Financial leverage and firm value. Unpublished Master's thesis. Gordon Institute of Business Science. University of Pretoria. South Africa.

28. Rappaport, A. (1998). Creating Shareholder Value: A Guide for Managers and Investors. New, York: Free Press.

29. Sagner, J. S. (2007). Why working capital drives M \& A today. Journal of Corporate Accounting and Finance, 2, 41-45.

30. Sharma, A. K., and Kumar, S. (2011). Effect of working capital management on firm profitability: Empirical evidence from India. Global Business Review, 1(1), 159-173.

31. Shin, H. H., \& Soenen, L. (1998). Efficiency of working capital management and corporate profitability. Financial Practice and Education, 8, 37-45.

32. Smith, K. V. (1980). Profitability versus Liquidity Trade-offs in working capital management. Readings on the Management of Working Capital, 549-562.

33. Smith, K. V. (1973). State of the art of working capital management. Financial Management, 2(3) (Autumn), 50-55.

34. Smith H., Blignaut, J. N. and van Heerden, J. H. (2007). An analysis of inventory investment in South Africa. Retrieved from http://www.repository.up.ac.za/bitstream/handle/2263/3505/Smith_Analysis(2006).pdf?sequence $=1 \&$ isAllowed $=\mathrm{y}]$

35. Smith, B. M., and Fletcher, L. (2009). Factors influencing working capital management in South Africa. Management Dynamics, 19(1), 2-10.

36. Soenen, L. A. (1993). Cash conversion cycle and corporate profitability. Journal of Cash Management, 13(4), 53-58.

37. Strischek, D. (2003). The Impact of Working Capital Investment on the Value of a Company. The RMA Journal, April, 48-55.

38. Taffler, R. (1984). Empirical models for the monitoring of UK corporations. Journal of Banking and Finance, $8(2), 199-227$.

39. Tangen, S. (2003). An overview of frequently used performance measures. International Journal of Business and Management, 5, 155-161.

40. Watson, D., and Head, A. (2010). Corporate Finance Principles \& Practice. Fifth edition. Pearson Education Limited.

41. Weinraub, H. J., and Visscher, S. (1998). Industry practice relating to aggressive conservative working capital policies, Journal of Financial and Strategic Decisions, 11(2), 39-46.

42. Weston, J. F., \& Brigham, E. F. (1972). Managerial finance. New York: Holt, Rinehart and Winston

43. Wilner, Benjamin S. (2000). The Exploitation of Relationships in Financial Distress: The Case of Trade Credit. Journal of Finance, 55(1), 153-178. 